\title{
砕波帯における放水ロマウンド被覆材 （シーサップブロック）の安定性について \\ STABILITY OF ARMOR UNITS (SEASUP CONCRETE BLOCK) OF DISCHARGE CHANNEL MOUND IN THE SURF ZONE
}

\author{
八木典昭 $1 \cdot$ 目見田哲 $2 \cdot$ 寒沢智 $3 \cdot$ 新幸弘行 4 \\ Noriaki YAGI, Tetsu MEMITA, Satoru SAMUSAWA and Hiroyuki NIKKOU
}

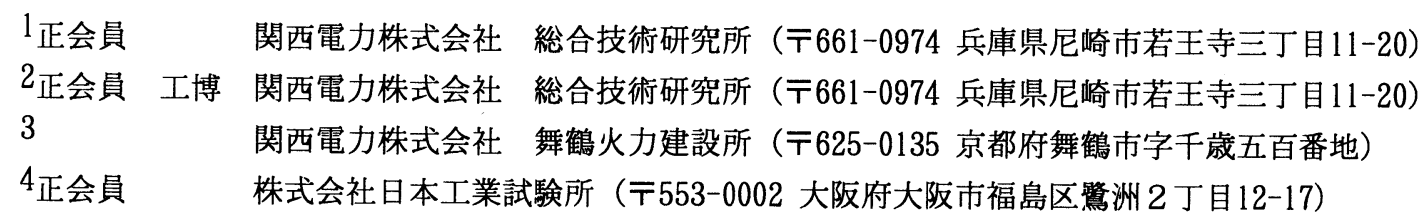

A series of hydraulic model experiments are conducted to investigate the stability of armor units using SEASUP concrete block for discharge channel mound in the surf zone. The effect of wave breakig on the stability of the block is noticeable. The stability of the block is influenced by the water velocity $\left(\mathrm{V}_{\max }, \mathrm{V}_{1 / 10}\right)$ on the mound.

Key Words : Discharge channel, rubble mound foundation, SEASUP concrete block, surf zone, hydraulic model experiment

\section{1.はじめに}

放水口は汽力発電所で使用した冷却水を放流する ための構造物である．放水口のマウンドが波の作用 に対して変形しないように，十分大きな石またはコ ンクリートブロックで被覆するのが通常である.

本論文ではシーサップブロックで被覆した場合を 対象とする. シーサップブロックは図ー1に示すよ うにブロック同土を膤み合わせること，および形成 された開口によって，耐波安定性が高いマウンドを 造ることが可能である ${ }^{1)}$.

耐波設計において, 被覆材が安定な質量（所要質 量）の算定には，適切な算定式を用いる必要がある.

混成堤の被覆消波ブロックの所要質量は, 従来は $\mathrm{K}_{\mathrm{D}}$ 值を用いたハドソン式 ${ }^{2)}$ よって算定されていた が，より精度の高い算定法が要求されてきている.

最近, 安定数 $\left(\mathrm{N}_{\mathrm{S}}\right)$ を用いたハドソン式が用いら れるようになっている。例えば，被害の大きさ・波 の作用時間・砕波の影響を取り込んだ $\mathrm{N}_{\mathrm{S}}$ の算定式 が提案されている (高橋ら ${ }^{3)}$ )。

混成堤のマウンド被覆材の所要質量は, 従来より, $\mathrm{N}_{\mathrm{S}}$ を用いたハドソン式によって算定されている (Brebner - Donnel1 $\mathrm{y}^{4)}$ ).

人エリーフは，天端が静水面下にあるという点で は，本論文で扱う放水ロマウンドと同じである．被
覆材（捨て石）の所要質量は，堤体表面の流速を用 いる算定法が提案されている(宇多ら ${ }^{5)}$ )。この算 定法では，堤体本体の変形を許容した状態での被覆 材の所要質量が算定されている.

一般に，砝波を伴う場合，流速を正確に評価する ことが困難な場合がある。よって，波高を用いて被 覆材の所要質量を算定できるハドソン式が用いられ ることが多い。例えば，エックスブロック（浅川ら $\left.{ }^{6)}\right)$, 全断面乱積みとしたテトラポッド (半沢ら ${ }^{7)}$ ) を 対象として $\mathrm{N}_{\mathrm{S}}$ の評価図が作成されている.

本論文で扱うシーサップブロックについても，規 則波の昜合の所要質量算定式が提案されている（長 谷川1).

しかし，マウンド上で，砕波が発生する不規則波 の場合の安定性は検討されていない。

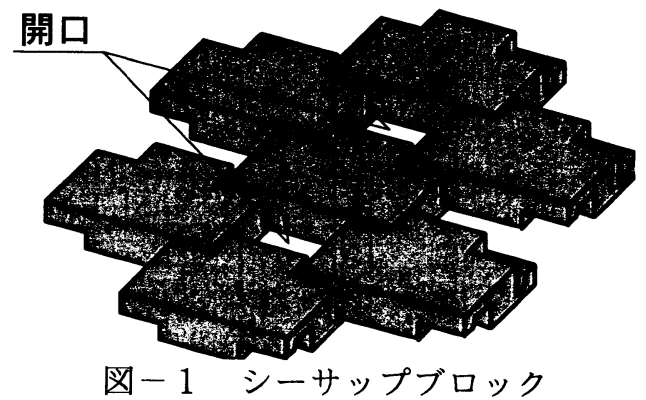


そこで，本論文では，崩れ波砕波を含む不規則波 を用いて，放水ロマウンドを被覆するシーサップブ ロックの安定性を実験的に検討する.その際に, 波 高分布や流速分布と, ブロックの安定性との関連性 についても検討する.

\section{2. 実験の概要}

\section{（1）実験水槽および海底勾配}

実験は，図一 2 に示す関西電力侏総合技術研究所 の造波水路（長さ $50 \mathrm{~m} \times$ 幅 $1.0 \mathrm{~m} \times$ 高さ $1.2 \mathrm{~m}$ ）にお いて行った。模型縮尺は, 一次元不規則波造波装置 （幅 $1.0 \mathrm{~m} \times$ 高さ $1.2 \mathrm{~m} ）$ の造波性能と, 造波水路の 大きさを勘案して $1 / 50$ とする. 造波水路には造波 板より $550 \mathrm{~m}$ 離れた位置から約 $1400 \mathrm{~m}$ の範囲に $1 / 50$ 程度の海底勾配を再現し，水深 $17 \mathrm{~m}$ の位置に は放水口マウンドが存在する。 なお，放水口からの 放流は再現していない.

\section{（2）放水ロマウンドの形状}

放水ロマウンド（幅約 $110 \mathrm{~m} \times$ 長さ約 $80 \mathrm{~m} ）$ は, シーサップブロック（5t : 長さ $1.5 \mathrm{~m} \times$ 幅 $2.3 \mathrm{~m} \times$ 高さ0.75m）で被覆し，図一 3 に平面図と断面図を
示すように，3タイプ（基本形状, $\mathrm{A}$ 形状, $\mathrm{B}$ 形 状）について検討する.

基本形状のマウンド天端のブロック（天端：DL$11.2 \mathrm{~m}$ ）は，放水管（天端：DL-10.4m）より低く なる.ここでは，ブロックに速い流れが直接には作 用しにくくなるために安定性は高くなる可能性があ るものの，放水管の存在によりブロックの噛み合っ ている範囲が狭いために安定性が低くなる可能性も 考えられる.

そこで，ブロックの安定性に及ぼす放水管の影響 を検討するために，A形状，B形状についても対象 とする（図一 3 参照）。 A 形状はブロック（天端： DL-9.7m）が放水管（天端：DL-10.4m）より高い タイプであり，ブロックの陱み合っている範囲は狭 い. $\mathrm{B}$ 形状はブロックのみで，放水口・放水管がな いタイプであり，ブロックは全体的に噛み合ってい る.

図中の太線で囲んだ範囲をマウンド天端と呼ぶ. マウンド天端は一様水深であり，法面勾配は $1 ： 4$ である、なお，実験においては，3タイプとも，平 面図に示すようにマウンドのうち; 幅 $50 \mathrm{~m}$ 再現す る.

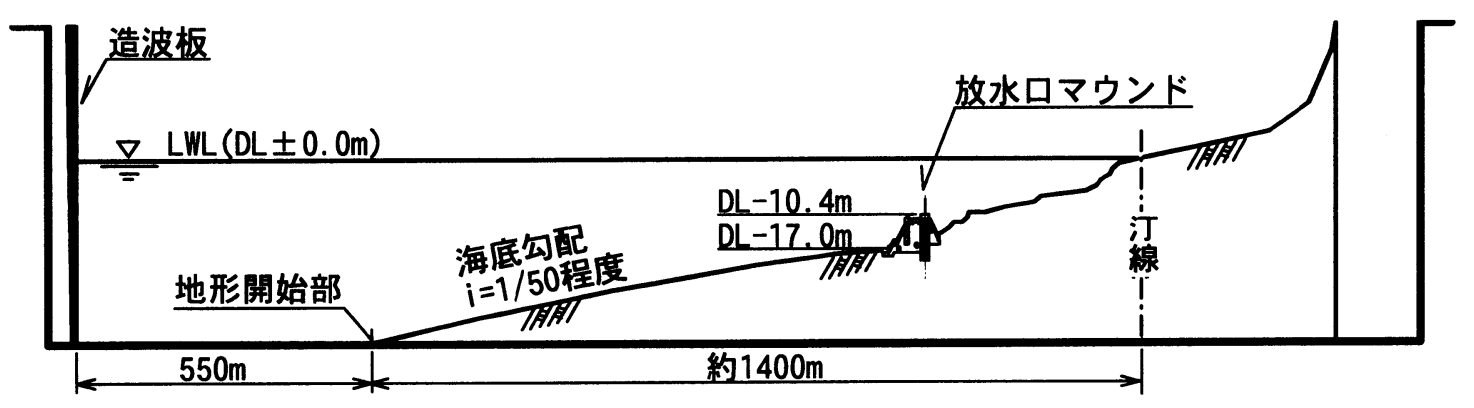

困-2 海底勾配と構造物

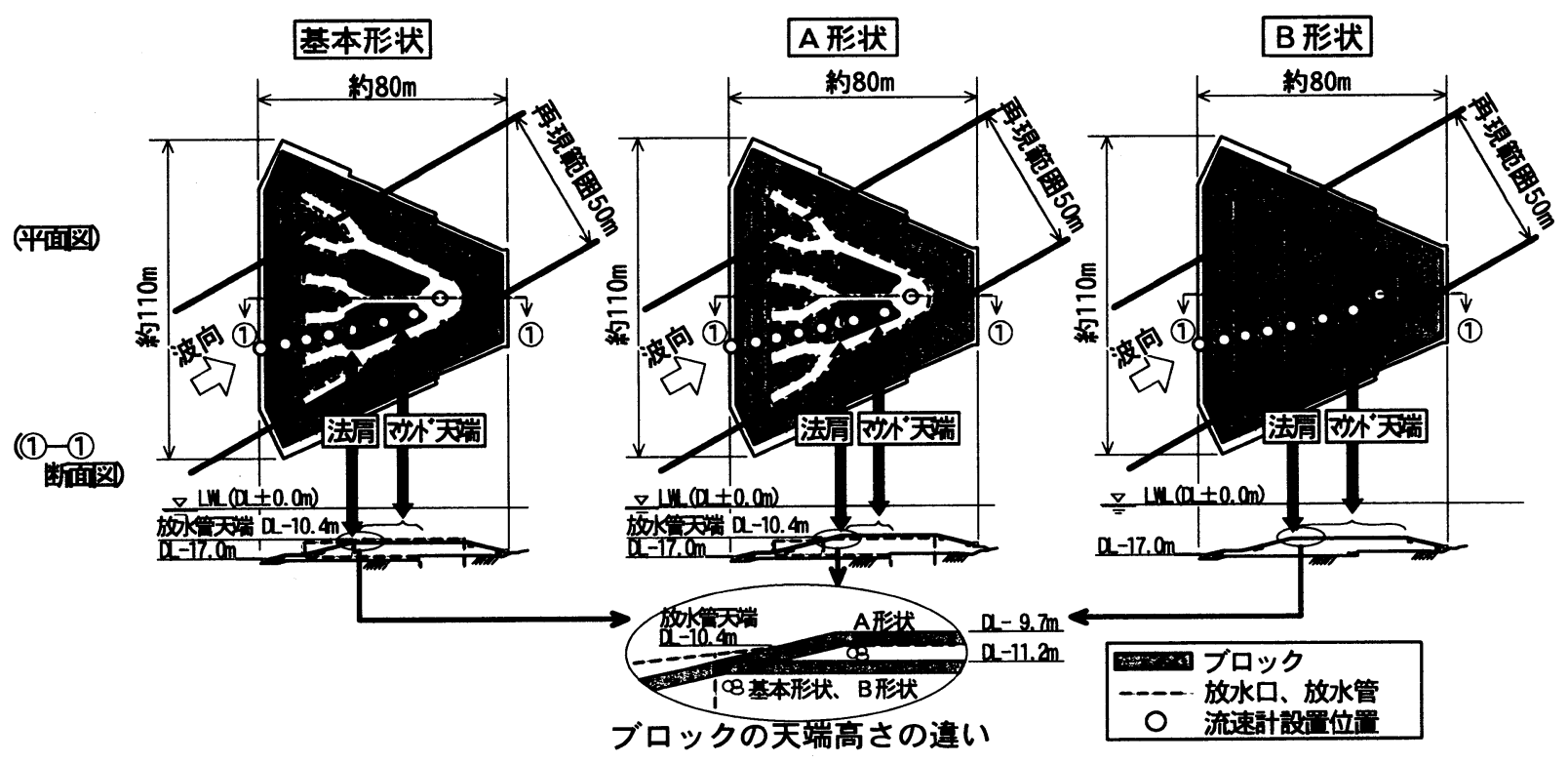

図-3 放水ロマウンドの形状 
（3）波浪条件

周波数スペクトルは地形開始部で確認し， Bretschneider-光易型とする．表一 1 に示す波浪条 件は，放水口（設置予定位置）中心への入射波の有 義波高と有義波周期である.

砕波が発生することが, 被覆材の安定性に強い影 響を及ぼすものと考えられる。そこで，どの波浪条 件にもマウンド上で崩れ波砕波を含む．なお，ケー ス 1 は浅いマウンド天端を中心に砕波が発生してお り，有義波高が大きくなるに従って砕波の中心はマ ウンドの深い範囲（ケース 2)，マウンドの沖 （ケース 3）と変化する. なお, 有義波周期が長い ケース 3 の場合は, 浅いマウンド天端で, 波の前面 がやや切り立ったような砕波も含まれている.

\begin{tabular}{|c|c|c|c|}
\multicolumn{2}{c}{ 表 -1} & \multicolumn{2}{c|}{ 波浪条件 } \\
\hline ケース & 1 & 2 & 3 \\
\hline 有義波高(m) & 4.5 & 6.4 & 7.5 \\
\hline 有義波周期(s) & 13.7 & 13.7 & 15.8 \\
\hline
\end{tabular}

\section{（4）測定項目}

まず, ブロックの安定性実験を行い，次にブロッ クを固定して，マウンド上の波高分布・流速分布の 測定実験を行う。実験時間は，約50分（ケース 1 ・ 2 : 約 240 波, ケース 3 : 約210波) である.

ブロックの安定性実験では, 同一のマウンド形状 に対して，まず有義波高の小さいケース 1 から作用 させ，順次，有義波高の大きいケース 2 ，ケース 3 を作用させる．なお，ブロックの移動が見られた場 合には，次の有義波高の大きな波は作用させない。

安定性の判定は, 目視によって, 移動・安定の 2 種類に分類する. ブロックの位置が移動する場合， および数秒間ブロックが浮き上がり元に戻る場合も 移動とする.

被覆材の安定性の考え方としては，多少の変形を 許容した設計も可能と考えられる。例えば，混成堤 の被覆消波ブロックについては，期待被災度の計算 法が提案されている(高橋ら ${ }^{3)}$ )。

しかし，本論文で対象とするシーサップブロック は，一層被覆材であり，わずかなブロックの移動か ら, 中詰の石材の逸散に一つな゙る可能性が高いため, ブロックが全く移動しない場合のみ安定とする.

波高分布・流速分布測定実験では, 図一 3 に示す 放水ロマウンド上の測点で, 波高と水平流速（ブ ロックの直上 $60 \mathrm{~cm})$ を同時に測定する. 波浪条件は， ケース 1，2，3である（表 -1 参照）.

\section{3. 実験結果および考察}

\section{（1）シーサップブロックの安定性}

本節では, ブロックの安定性を, 特に, マウンド 天端に注目して把握する。なぜなら，浅いマウンド 天端は砕波の影響を強く受けること，およびブロッ クは沖側法肩で不連続であることから、ブロックが
移動しやすいと考えられるためである.これ以降,

本論文では, 沖側法肩を, 単に法肩と記述する.

基本形状のブロックは安定であった.

それに対して，A形状はケース $2 ， \mathrm{~B}$ 形状はケー

ス3によって、ブロックの移動が見られた。

両形状における, ブロックの移動は，法肩付近で 䂶波が発生する 1 波によって見られた。 また，移動 するまでのブロックの挙動を観察した結果, 動摇は 見られなかった。

また, ブロックの安定性は, 放水管の影響を強く 受け，位置（高さ）関係によっては，噒み合ってい る範囲が狭くても安定性が高い場合もある.

なお，砕波しない規則波の場合の算定式（長谷川 7)）によって，不連続部を有する場合の所要質量を 算定すると $1 \mathrm{t}$ 末満となり, 今回の実験結果とは大 きな差が見られる。

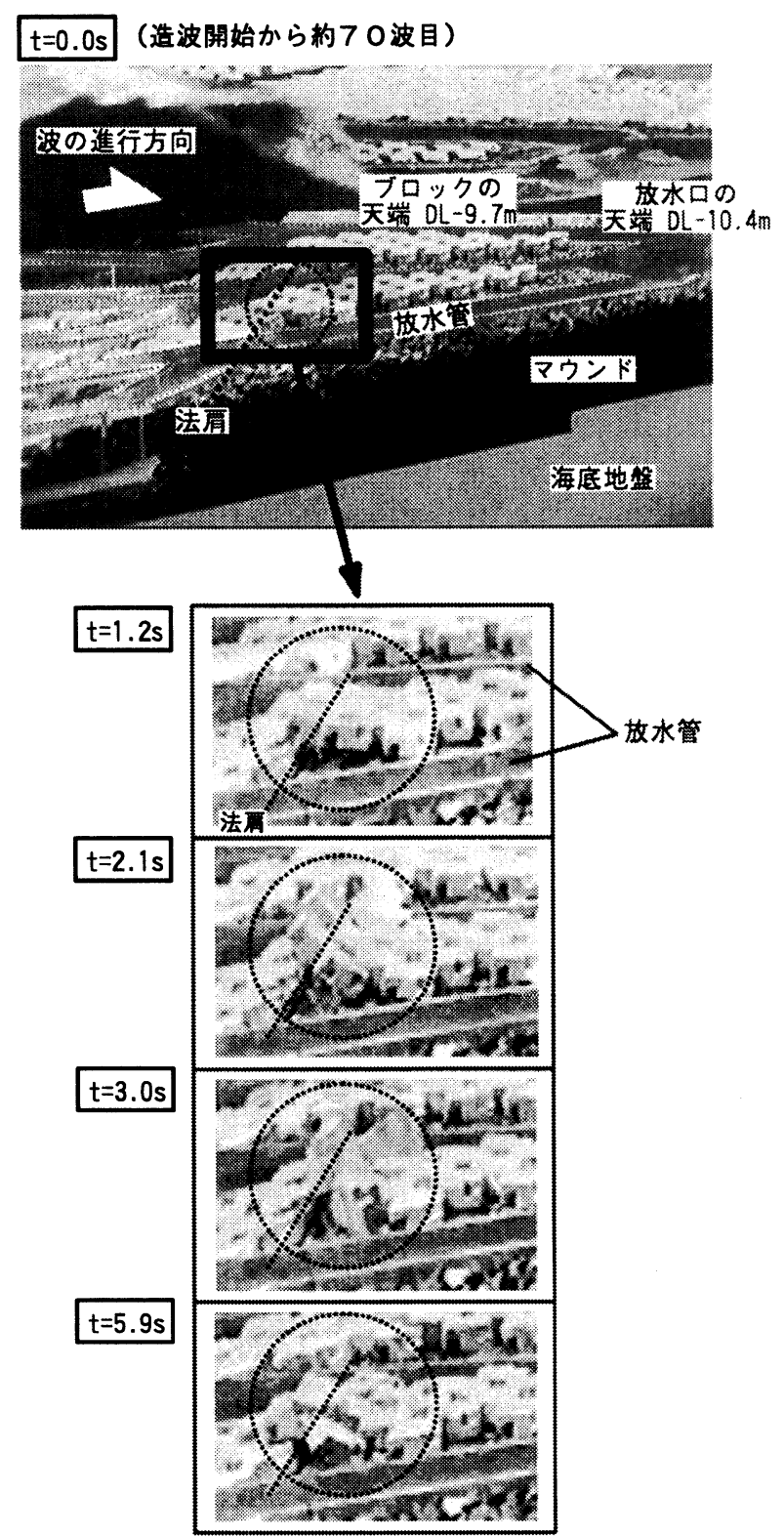

写真一 1 移動する際のブロックの挙動（A形状） 
写真一 1 に, ブロックが移動する際の挙動の一例 を示す。ここでは, ブロックが高く浮き上がった， $\mathrm{A}$ 形状の約半周期間の挙動を示す.

1 枚目（ $\mathrm{t}=0.0 \mathrm{~s} ）$ の写真は造波水路側面から撮 影したものであり，ブロックのほかに，マウンド， 放水口，放水管，海底地盤が見える，なお， 2 枚目 $(t=1.2 \mathrm{~s})$ 以降の写真は, ブロックが移動した法 肩付近を拡大して示す.

1 枚目の写真は, ブロックが移動する直前であり, 造波開始から約70波目で, 法肩付近を, 崩れ波砕波 を伴う波の峰が通過しつつある. 2 枚目は，マウン ド天端において法肩を端部として，岸の方のブロッ クまで連なって浮き上がっている．３枚目では，端 部のブロックが, 更に高く浮き上がっている. 4 枚 目では，端部のブロックの噒み合わせがなくなり， バラバラになっている．5枚目では，浮き上がった ブロックが斜面上端に乗り上げている.

なお，写真は示していないが， B 形状のブロック も同様に，法肩から岸の方のブロックまで連なって 浮き上がった.

（2）マウンド上の波高分布，流速分布

本節では，ブロックの安定性と，マウンド上の波 高分布や流速分布との関連性を考察する.

\section{a）波高分布との関連性}

まず，波高分布と安定性との関連性を検討する.

図一 4 に， A 形状・B形状でブロックが移動した 際（おのおの，ケース 2 ・ケース 3)，および安定 であった基本形状（ケース３）の波高分布を示す.

ブロックの移動は，前節で述べたように，不規則 波群中の砕波が発生する 1 波によって見られた。ま た，ハドソン式においては, 有義波高 $\left(\mathrm{H}_{1 / 3}\right)$ を用 いて所要質量を算定される。よって，図ー4では, 最高波高 $\left(\mathrm{H}_{\max }\right)$ と有義波高に注目して, 波高分布 を示す.

安定であった基本形状と，移動したB形状の波高 分布はほぼ同じである。また，波高分布が全体的に 小さい, A形状でブロックの移動が見られた。

これらより, 波高分布 $\left(\mathrm{H}_{\max }, \mathrm{H}_{1 / 3}\right)$ と, ブロッ クの安定性はあまり対応していないことが確認でき る.
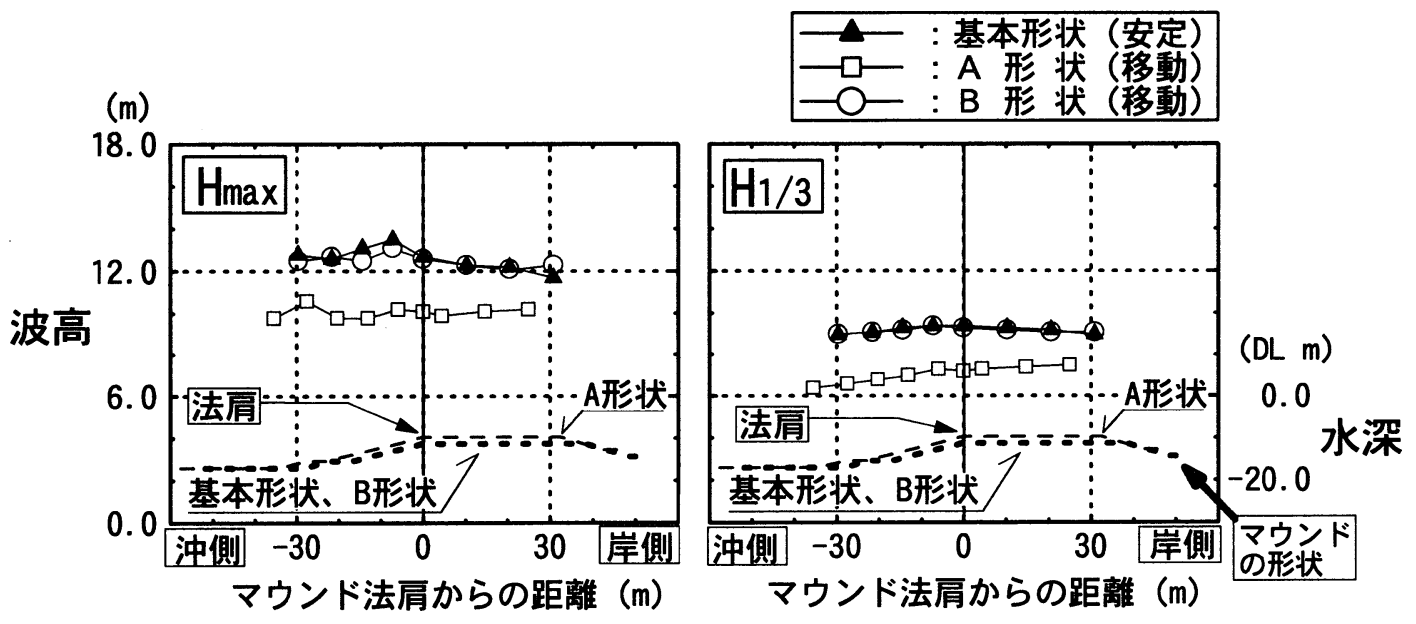

図-4 マウンド上の波高分布（基本形状， A 形状， B 形状）
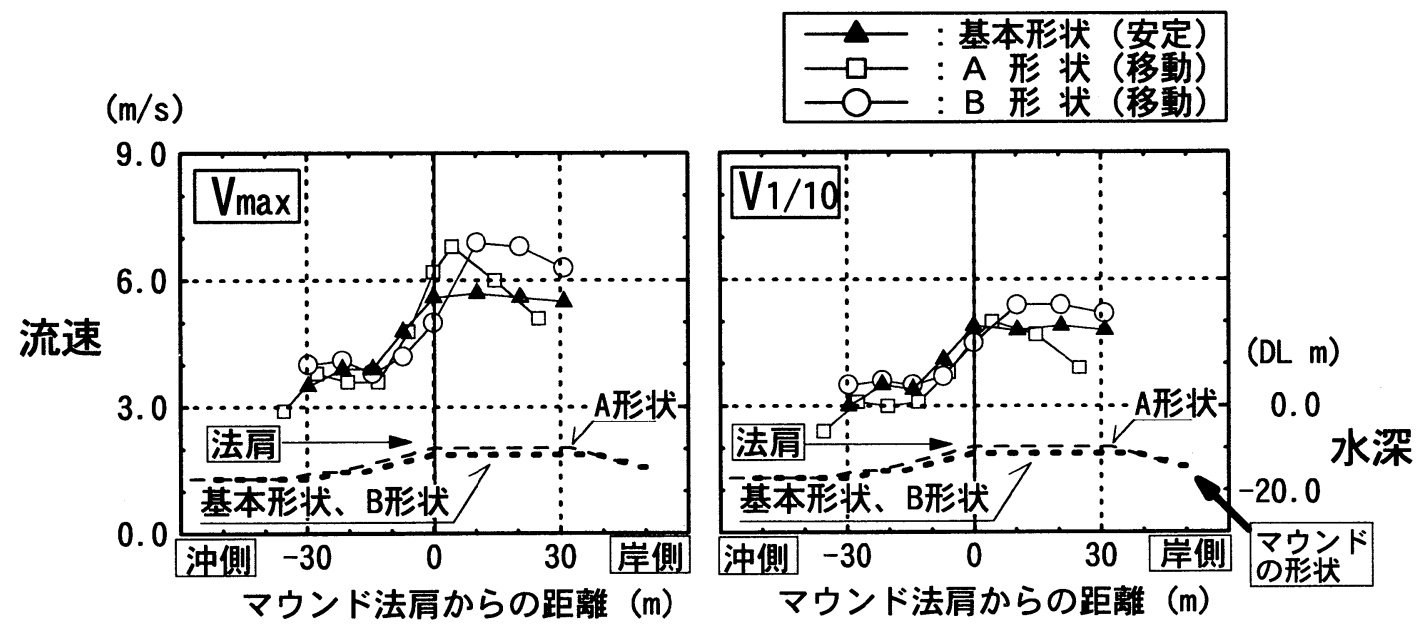

図－5 マウンド上の流速分布（基本形状, A 形状, B 形状） 


\section{b）流速分布との関連性}

次に，流速分布と安定性との関連性を検討する.

ブロックの移動は，前節で述べたように，法肩付 近で研波が発生する一波によって見られており，こ の時, ブロックには速い流れが作用していると推定 できる。ここでは， $\mathrm{V}_{\max }$ もしくは， $\mathrm{V}_{1 / 10}$ と安定性と の関連性を検討する.

図一 5 に，図 -4 と同じ波浪条件での流速分布 $\left(\mathrm{V}_{\max }, \mathrm{V}_{1 / 10}\right)$ を示す.

まず， $\mathrm{V}_{\max }$ の分布に注目する.

ブロックの移動が見られた A 形状と B 形状とも， 流速分布のピーク值はマウンド天端で発生し，その ピーク值はほぼ同じである.

それに対して，ブロックが安定であった基本形状 のマウンド天端は，3章 2 節でも述べたように，放 水管天端より低いため, ブロックに速い流れが直接 には作用しにくいと考えられ，流速分布は全体的に 遅い。これがブロックの安定につながったものと考 えられる。

今回検討した波浪条件においては，A形状，B形 状とも，ブロックが移動した時刻と，最大流速

$\left(\mathrm{V}_{\max }\right)$ が発生した時刻はほぼ同じであった。ブ ロックの安定性は, ブロック直上の流速 $\left(\mathrm{V}_{\max }\right)$ に 大きく関連していると考えられる.

ブロックの移動が見られたのは，結果的に法肩付 近であったが, 法肩での流速は速い順に A 形状（移 動），基本形状（安定）， B 形状（移動）であり，
1 点のみの流速によってブロックの安定性を述べる ことは困難と考えられる。なおかつ，前節で述べた ように，ブロックが連なって浮き上がったことを併 せて考えると，速い流速が発生したマウンド天端の 広い範囲について流速分布を評価することが必要で ある（写真 -1 参照）

次に， $\mathrm{V}_{1 / 10}$ の分布に注目すると， $\mathrm{V}_{\max }$ ほどではな いものの, ブロックの安定性との関連が見られる.

\section{（3）マウンド上での流速分布のピーク発生位置}

前節で述べたように，ブロックの安定性は，マウ ンド上の流速分布（ $\left.\mathrm{V}_{\max }, \mathrm{V}_{1 / 10}\right)$ に大きく関連して いると考えられる，マウンド上の流速分布は，砕波 が発生する位置によって变化する可能性が高い.

そこで，図ー6には，図-5で示した以外の波浪 条件についても流速分布 $\left(\mathrm{V}_{\max }, \mathrm{V}_{1 / 10}\right)$ を示し，安 定性との関連性についてさらに検討を進める.

それぞれのマウンドにおける流速分布の形状は， ほとんど同じである.

また，A形状・B形状については，ブロックの移 動が見られた法肩において，流速分布のピークが発 生しているわけではない。このことから，法肩付近 でブロックの移動が見られたのは，ブロックが不連 続であることの影響を強く受けているためと考えら れる.よって，部分的に法肩付近のブロック質量を 増すことにより，更に高い安定性が期待できる.
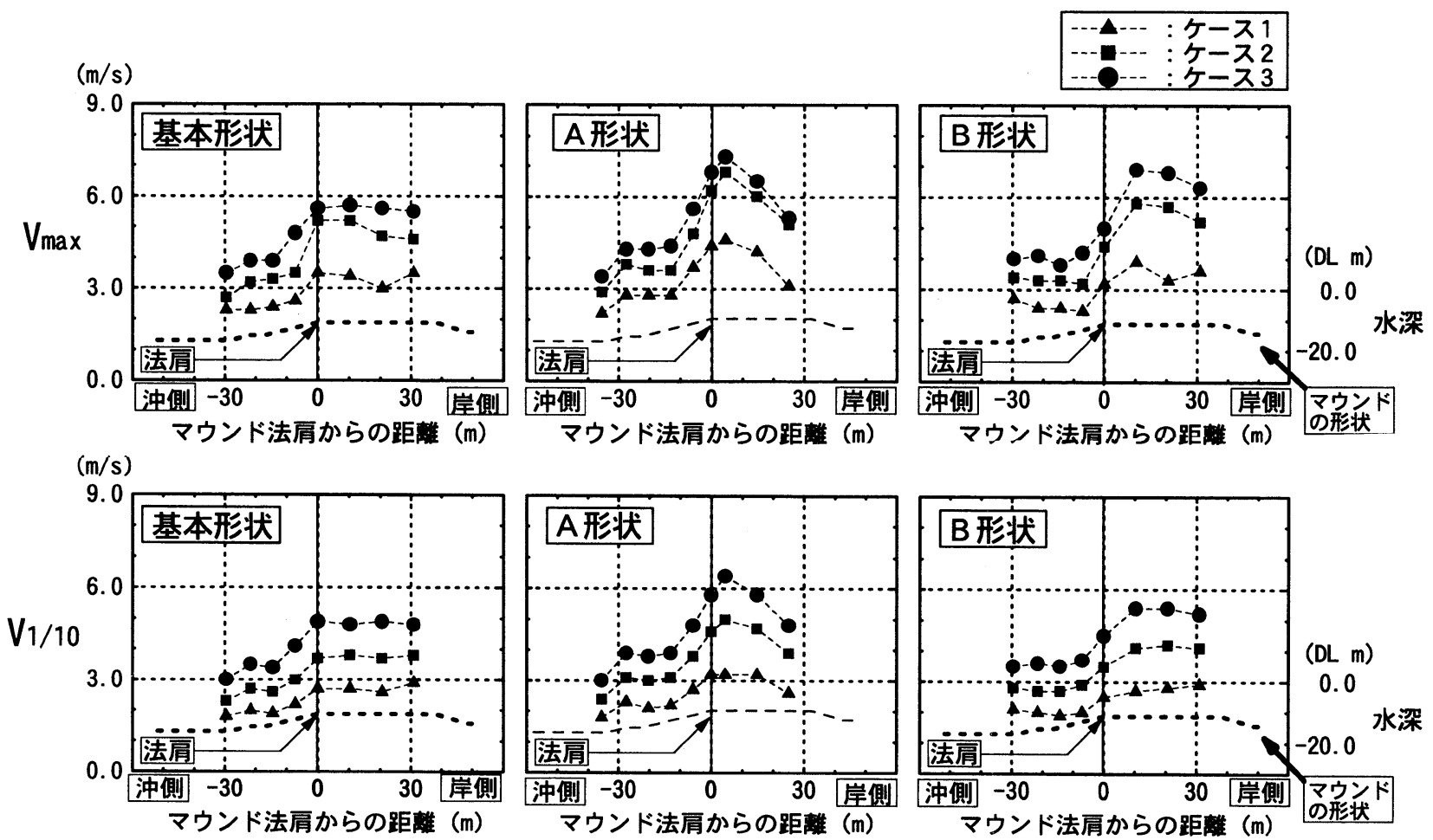

図－6 マウンド上の流速分布のピーク発生位置（ケース 1，ケース 2 ，ケース 3) 


\section{4. 結 論}

今回, 砕波する不規則波を用いて, 放水ロマウン ドを被覆するシーサップブロックの安定性を把握し た. 特に, マウンド上の波高分布や流速分布と, ブ ロックの安定性との関連性について考察した. 本研究による主な結論を以下に要約する.

(1) ブロックの天端が放水管よりも高いタイプ（A 形状），およびブロックのみで放水口・放水管が ないタイプ（B形状）においては, ブロックの移 動が見られた。

それに対して，ブロックの天端が放水管よりも 低い基本形状においては，いずれの波浪条件につ いてもブロックは安定であった.

(2) 移動する際のブロックの挙動を詳細に観察する と, 不規則波群中の, 法肩付近で砕波が発生する 一波によって移動し, 法肩から岸の方のブロック まで連なって浮き上がった．ブロックは単体でな く, 複数で噒み合って高い耐波安定性を発揮して いることが確認できる.

（3）砕波が発生する場合のブロックの安定性は，波 高 $\left(\mathrm{H}_{\max }, \mathrm{H}_{1 / 3}\right)$ ではなく、ブロック直上の流速 $\left(\mathrm{V}_{\max }, \mathrm{V}_{1 / 10}\right)$ に大きく関連している. また, (2) で述べたようにブロックが連なって浮き上がった ことを併せて考えると, 法肩だけでなく，速い流 速が発生したマウンド天端の広い範囲について流 速分布を評価することが必要である.

(4) ブロックはマウンド法肩で不連続であり，(2)で 述べたように，その部分で移動が見られた。この ことから, 部分的に法肩付近のブロック質量を増 すことにより，更に高い安定性が期待できる.
謝辞：本研究を遂行するに当たり, 電力中央研究所 榊山上席研究員から終始, 御指導を頂きました。こ こに記して感謝の意を表します。

\section{参考文献}

1) 長谷川寛：海底放水管の被覆工に関する設計手法の提 案, 電力中央研究所報告, 研究報告U90014, 1990 .

2) Hudson, R.Y.: Laboratory investigation of rubble-mound breakwater, Proc. ASCE. Vol.85 W.W.3. , pp.93-121, 1959.

3) 高橋重雄, 半沢稔, 佐藤弘和, 五明美智男, 下迫健一 郎, 寺内潔, 高山知司, 谷本勝利：期待被災度を考慮 した消波ブロックの安定重量一消波ブロック被覆堤の 設計法の再検討，第 1 報一，港湾技術研究所報告 第 37巻 第 1 号, pp. 3-32, 1998.

4) A. Brebner, and D. Donnelly: Laboratory study of rubble foundations for vertical breakwaters, Proc. $8^{\text {th }}$ Conf. of Coastal Eng., pp.408-429,1962.

5) 宇多高明, 小俣篤, 斎藤友信 : 人エリーフ被覆材の所 要重量算定法，土木研究所資料，第 2893 号，48p. , 1990.

6)浅川勉，佐藤弘和，口ノ町誠，野口正昭：人エリーフ 被覆材の安定性に関する実験的研究, 海岸工学論文集, 第39巻, pp. 656-660, 1992.

7)半沢稔, 周遠強, 杉浦淳, 佐藤弘和：消波ブロックを 用いた人工リーフの機能・安定性に関する実験的研究, 海岸工学論文集, 第43巻, pp. 821-825, 1996. 